Revue de l'Institut des langues et cultures

d'Europe, Amérique, Afrique, Asie et Australie

39 | 2020

Les humanités numériques dans une perspective internationale : opportunités, défis, outils et méthodes

\title{
Digital, Experiential, and Embodied: Reckoning with the Past in Putnam County, Georgia
}

Numérique, expérience et incarnation : Échanger avec le passé dans le comté de Putnam, en Géorgie

Christopher R. Lawton, Theodore J. Kopcha, Katie Walters and Ceren Ocak

\section{OpenEdition}

\section{Journals}

Electronic version

URL: http://journals.openedition.org/ilcea/9533

DOI: $10.4000 /$ ilcea.9533

ISSN: 2101-0609

Publisher

UGA Éditions/Université Grenoble Alpes

Printed version

ISBN: 978-2-37747-174-4

ISSN: $1639-6073$

Electronic reference

Christopher R. Lawton, Theodore J. Kopcha, Katie Walters and Ceren Ocak, « Digital, Experiential, and Embodied: Reckoning with the Past in Putnam County, Georgia », ILCEA [Online], 39 | 2020, Online since 03 March 2020, connection on 10 October 2020. URL : http://journals.openedition.org/ilcea/ 9533 ; DOl : https://doi.org/10.4000/ilcea.9533

This text was automatically generated on 10 October 2020

(C) ILCEA 


\title{
Digital, Experiential, and Embodied: Reckoning with the Past in Putnam County, Georgia
}

\author{
Numérique, expérience et incarnation: Échanger avec le passé dans le comté de \\ Putnam, en Géorgie
}

Christopher R. Lawton, Theodore J. Kopcha, Katie Walters and Ceren Ocak

Acknowledgements: Putnam County High School students and teachers contributed to the research and writing of this account of the place they call home. We are particularly indebted to PCHS student Deon Hill, as well as his colleagues Ke'aundre Battle, Destiny Beltman, Kimmie Bonner, Kaylan Clemons, Alma Escutia, Raymond Ewing, Simone Gibson, Calissa Hayman, Sonia Hernandez, Hannah Lanier, Nancy Martinez, Angie Monroy, Jake Morris, James Mead, Maribel Nieto, Alex Olive, Kacie Ruff, Nadalie Shifflett, and Darrez Walker, as well as teachers, Cecile Deen, Jonathan Deen, Kara El-Kadi, and Andrew Grodecki. We are also grateful for the research guidance provided by Putnam County Probate Judge Patrice Underkofler and her staff, as well as local historian Mr. James Marshall.

This work would not be possible without the sustained leadership of the Putnam County school system superintendent Eric Arena. We are also deeply appreciative of the support of Dr. Nicholas Allen, Director of the Willson Center for Humanities and Arts at the University of Georgia. GVHP has always been a collaborative effort, and we are deeply grateful to the contributors who have helped from the project beginnings. This includes but is not limited to: Mark Evans, Dr. John C. Inscoe, Laura Nelson, Dr. Randy Reid, and Kiersten Rom.

1 Digital Humanities has reshaped the ways in which knowledge is conceptualized, visualized, and shared. The 2016 volume of Debates in the Digital Humanities identifies data visualization, 3D modeling, and data mining large sets of cultural data as the most common ways academics and non-academics alike characterize current advances in the field (Klein \& Gold, Ix). For some, these activities have come to define the scope of the discipline. Yet for others, this has limited the potential for humanistic scholars to engage with new questions and new technologies. The editors of A New Companion to Digital Humanities noted this limitation, reminding us that, "What is important today is 
not that we are doing work with computers, but rather that we are doing the work of the humanities, in digital form" (Schreibman et al., XVII).

Projects that are overly focused on the potential of technology cannot be a panacea for the much-bemoaned demise of the liberal arts. Indeed, they may work against their common cause. As William Pannapacker noted in the Chronicle of Higher Education, this focus on technology often "ill-suits [the] teaching mission" of those concerned with connecting humanities content with their students' lives. Pannapacker further explained how the field of digital humanities has been characterized as "elitist and exclusive because it requires the resources of a major university." This unfortunate reputation has often led liberal arts faculty and high school teachers alike to eschew opportunities to engage with the field, even if they find it admirable.

In this paper, we present a digital humanities initiative we call the Georgia Virtual History Project (GVHP). Rather than simply creating digitized humanities, GVHP explores the ways in which the digital world can help construct more robust, placebased scholarship that impacts the lives of those who make and use it. The goal of the project is to create content that exists both in real and digital spaces, speaks equally to scholars and the general public, and demonstrates that the humanities are not the purview of the academic elite but rather an essential tool for reaching out and amplifying the voices of traditionally underserved populations.

Whereas some projects are built to exist only in a digital space, GVHP aims to create digital pieces that exist in the spaces of the outside world. We achieve this by cultivating human connection, where students, teachers, and community members participate in and contribute meaningfully to the project. As Matthew Kirschenbaum noted, "[D]igital humanities is also a social undertaking. It harbors networks of people who have been working together [...] a culture that values collaboration, openness, nonhierarchical relations, and agility" (197). From this perspective, the term "digital" is not simply a new descriptor of a traditional project, or a project that seems newish because it employs digital tools to reach old ends. Rather, it is about meaningfully reframing how and why we collect and employ data, and the impact of that work on the students doing it.

5 The focus of project activity is therefore on uncovering, constructing, and telling stories of people's lives that were previously untold, and connecting these stories across time and space. Students participating in the Georgia Virtual History Project (GVHP) attempt to not only gain perspective on the past, but also build meaningful connections from the past to the present by learning about the history of their community through the lives that shaped it. This approach emphasizes understanding the relationships between historical events and the people who lived them, rather than seeing history as sets of facts and events to be memorized. Students are encouraged to discover, research, and share stories from their community's past as a way of imbuing those events with new life, meaning, and potential for shaping the future. The goal is not only to help them learn historical content, but also, and in more profound ways, to develop historical consciousness.

6 Rather than handing off a completed effort made by academics in a university lab, we built the effort in partnership with the public school system and community members in rural, economically-disadvantaged Putnam County, Georgia. This grew out of a fiveyear partnership between GVHP, the Willson Center for Humanities and Arts at the University of Georgia, and the Putnam County schools. The support of the school 
system was critical to the project; Putnam's public K-12 school system is unlike many systems in the United States. It was not only one of the first charter systems in the state, but school leaders have actively worked towards creating approaches to education that move beyond preparing students for standardized testing. Their goal has long been to prepare students for a future in which they both understand and contribute meaningfully to the health of their communities. The partnership between GVHP, a local school system, and the state's flagship institution reflects this focus on community-based education.

7 The partnership created ideal conditions for a unique process to emerge. Putnam's students worked with academic professionals to use digital tools to research the pasts through which their ancestors lived, turning the results of their research into digital content, thus enabling a process by which the students and their communities are both the manufacturers and consumers of their own history. This process, rather than the product itself, has potential to provide them with a unique set of skills for renegotiating the past, coming to terms with what it means to grow up in a place with a very complex history, and using digital humanities as a lens for reimagining K-12 education. Our goal is to create something that goes beyond the predominant focus on mastery and testing of mandated standards, instead using those standards to make well-educated and engaged citizens who understand who they are and where they come from.

\section{Place as Context}

8 If all American places have a complex history, perhaps few have as storied a past as Putnam County, Georgia. Putnam is a 360-square-mile landscape at the rural center of the state, an hour and a half drive southeast from Atlanta. At that far of a distance, the superhighways, skyscrapers, and cultural and economic possibilities of the metropolis fade from the imagination. Conspicuous consumption gives way to self-reliance measured out along small county roads and in the aisles of a single Wal-Mart and two chain grocery stores.

Putnam is a place, like so many other small places across the Deep South, trying to figure out how to survive in the 21st century. Its county leaders work to build bridges to the information economy they hope will come, but its byways and folkways sometimes evoke older and more agricultural systems of the past. The farms, mills, and manufacturing that once provided a living wage to its citizens are all but gone. What remains are gently rolling red clay hills and dense woods, rich and fertile farmland gone fallow, and a picturesque downtown waiting for the crowds of tourists and shoppers and diners that infrequently arrive. Undergirding it all is the razor-edged existence of those living in poverty in what, Putnam's students will tell you, used to be known locally as "pimp city." They contend daily with the same infrastructure of lost potential that has been left behind in many counties across the rural South: rented mobile homes and government-subsidized housing, limited access to healthy foods and healthcare, financial hardship, personal struggle, drugs, and violence.

Yet Putnam's present and the fight for its future have grown out of a remarkable past. The county was created in 1807 to organize the tide of poor and middling whites flooding into the area to settle on what promised to be incredibly rich cotton land. The wilderness soon gave way to settlement and agricultural production. Within a few 
decades, Putnam's cotton economy was generating unprecedented prosperity for some through the forced labor of thousands and thousands of enslaved others. According to the U.S. Census of 1860 , more than 7,000 people, or roughly $71 \%$ of the county's population, were held in bondage. Those 7,000, descended from untold others, gave Putnam a higher percentage of slaves than all but four of Georgia's 132 counties at the time. More to the point, the descendants of many of those 7,000 enslaved people still remain.

11 The majority of sites of enslavement have disappeared from the Southern landscape and faded from collective memory, leaving modern Americans with a vague knowledge of only a few to stand in for the many. Putnam, however, has been home to one of the best-known plantations in the nation, from the time of the Civil War through the present. Joseph Addison Turner began publishing small tracts from his Turnwold Plantation in the 1850s. A decade later, he and his apprentice, a teenage boy by the name of Joel Chandler Harris, began writing and publishing The Countryman newspaper from a printing office adjacent to both Turner's home and the cabins in which he housed his slaves. Each edition of The Countryman reached several thousand readers across the Confederacy and made its publisher and his plantation relatively famous. More importantly, it launched the career of his apprentice. Harris spent years living on the plantation, inhabiting a bedroom in Turner's house, eating with his family, and learning how to be a writer at the elbow of his mentor and surrogate father. He also learned the intricacies of slavery through his years at Turnwold, and through his close relationships with the people held in bondage there.

Harris' experiences at Turnwold are where Putnam's history is transformed from the story of so many places across the plantation South to something remarkable, both in potential for understanding the past and working towards the future. In 1880, nearly a decade and a half after leaving the plantation, Harris published the stories he learned from Turnwold's slaves as Uncle Remus, His Songs and Sayings. In short order, and as more Uncle Remus volumes followed, he became one of the most famous American authors on the planet. Putnam County proudly celebrated its native son. Harris wrote a special "Uncle Remus" story for Putnam to use in promoting itself at the 1895 Cotton States Exhibition. Putnam repaid the favor by erecting an iron statue of Harris' "Br'er Rabbit" on its courthouse lawn. By the mid-twentieth century, the county had turned two former slave cabins into The Uncle Remus Museum. By the beginning of the twentyfirst century, Br'er Rabbit signs marked every major byway entering into the county.

13 Generations of Putnam County's children, both black and white, have grown up with Harris, Remus, and Br'er Rabbit looming in the background of their lives. Yet in an age when the Harris books have fallen out of favor and Disney has permanently shelved the 1948 film version, nearly 100\% of Putnam's students engaged in this project acknowledge having never previously read a single Uncle Remus story. In the absence of any careful investigation of the material, the students, like their parents and grandparents and great-grandparents before them, rightly assume the county's monuments and signs celebrate Harris's work and accomplishments.

14 At the same time, those monuments represent what Jonathan Sterne claims in The Audible Past, are the "exteriorities" of which history is comprised. These exteriorities are symbolic, carrying different meaning for different people. For some, they are gauzy nostalgia made manifest in metal. For others, they are the tools of the tourist trade and a way of enticing outsiders to visit. For many of the descendants of the 7,000, however, 
they are deeply entrenched reminders of the horrors of the past, the stealing of their stories and history, and a celebration of the entrenched segregation that held them down. From this perspective, the remembrances of Harris and his work conjure feelings about a past that many in the county and, more broadly, the state prefer to remain hidden or forgotten.

Our goal in noting these varied perspectives is not to reopen old wounds. Rather, it is to show how historical exteriorities can be viewed and analyzed from different perspectives, open new meanings about the past and present, and support the development of historical consciousness. Below, we present a case study of a set of specific project activities presented as a story broken into four parts. Each part is explored as a unique "vantage point," a phrase borrowed from the educational psychologist Lynn Liben that describes the ability to view "a slice of the environment in a particular point time" (203). It is through this process that humans come to develop perspective. Mind and body naturally work together to make sense of and construct meaning about the world. As mind and body encounter new information, there is the potential to create new meaning or new vantage points. Thus, one's perspective of the world is based on one's ability to develop and connect multiple vantage points. This process can, in turn, lead to new information and, potentially, new vantage points.

Presenting our project in this way illustrates how GVHP challenges students' ways of knowing history. The racial makeup of Putnam County's public school system is roughly $44 \%$ white, $44 \%$ black, and $9 \%$ Hispanic. Eighty percent (80\%) of these children live in poverty, a shocking figure that is $20 \%$ higher than the state average. For many of Putnam's students, especially those in high school, traditional approaches to learning history and engaging with the humanities are disconsonant with their lives and interests. The emphasis on memorizing facts and dates for standardized testing purposes ultimately decontextualizes history. Our effort draws on the best of the digital humanities to reimagine the potential of what it can be as means for students to not only confront the past, but also create new roadmaps for the future.

\section{Vantage Point One}

The first vantage point begins in October 2016, when a group of Putnam County High School students gathered in fields of Turnwold Plantation. They had been learning about slavery in their U.S. History class and now sat in the grass at this former site of enslavement to read aloud Joel Chandler Harris' "The Plantation Witch." The tale, a chapter in Uncle Remus: His Songs and Sayings, presented them with the opportunity to consider the specific words and songs of the enslaved people Harris knew. In the story, Remus sings, "It's eighteen hundred and forty eight, Christ done made that crooked way straight-and I don't want to stay here no longer. [...] Run home, that sun done roll -And I don't want to stay here no longer" (243). The lyrics would have been an odd choice had Harris simply made them up but are even odder for the fact that he wanted his readers to know that he had not. To prove the authenticity of the words, despite his connecting them with a fictional character, Harris reproduced the song in its entirety in an appendix at the end of the volume. It is a provocative song, presented in an unexpected way, suggesting something profoundly important at work beneath Harris' choice of source material. More importantly, the song lyrics also led students to dig into the appendix. 

enslaved, within the context of this essay they are especially important as the seedbed out of which a project grew. Harris spent his entire childhood and adolescence enmeshed in the world of Putnam's wealthiest planters, even living in Turner's house at Turnwold for years, yet not a single one is mentioned by name in Uncle Remus: His Songs and Sayings. Even the material in the appendix is identified only by the county in which Harris heard it, but not by the names of planters or plantations. There is only one time in the entire volume when Harris names a name, a single line in the appendix suggests that he learned one song from slaves at the "Myrick Place, Putnam County, 1858" (238) [see Figure 1].

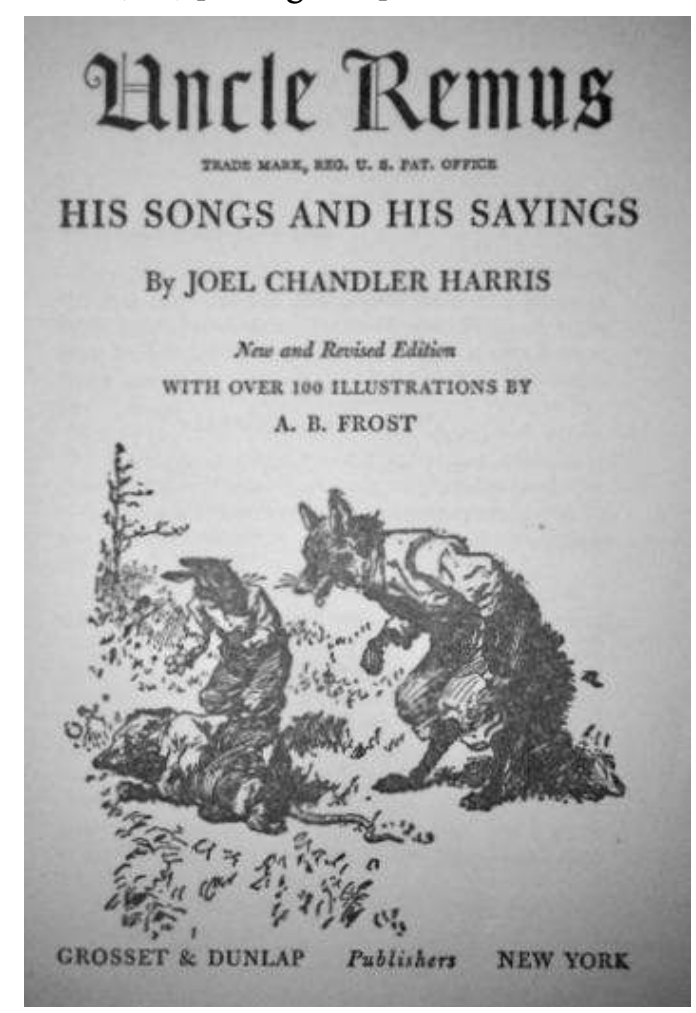

V

CHRISTMAS PLAY-SONG

(Mrrick Place, Putnam County-1858.)

Figure 1 - Title page (above) of Joel Chandler Harris, Uncle Remus, His Songs and Sayings (1880) and mention of "Myrick Place" in appendix (below). 

of questions: Who was Myrick? Why was this one name mentioned? How might his story relate to the bigger history of Putnam County, or Georgia, or even the American South?

21 The first vantage point, then, is the point at which an experience in the field of a local plantation launched a group of high school students into the act of doing history. The term doing history is used here with careful consideration and for good reason. Students are not simply memorizing facts and dates, but learning the methods and purposes of the historian's craft through first-hand experience. Peter Seixas, founding Director of the Centre for the Study of Historical Consciousness at the University of British Columbia, described doing history as using the methods of historical research for deeper understanding of one's own place in the world as well of that of those who lived in the past. These concepts do not represent a clear and linear process but, he argues, are issues students must actively engage with, "as problems, tensions, or difficulties that demand comprehension, negotiation and, ultimately, an accommodation [...]" (5). Finding Myrick's mention in the appendix had unintended results. It became an opportunity to actively engage with and deconstruct a 140-year-old text by connecting it to roots still hidden in the ground on which it was conceived. Digging for those roots allowed students to challenge the presumed authority of the printed word and the weight of history by resituating both in a real-world context in the community in which they live.

This investigation led students to employ new digital tools to search previouslyunderutilized records, as well as to compile and share what they found, enabling them to encounter the past with completely fresh eyes and renegotiate its meaning. They began by searching Putnam County wills and probate records in the online archives at familysearch.org, then created a Google Doc to track the information they found. The online primary sources generated a long list of details, and even more questions about Myrick and his circumstances. The students then visited the county archives at the local courthouse, working closely with the Probate Judge and her staff to learn how to search for materials beyond what was available online.

virtual and physical documents, students began to construct an understanding of the life of the "Myrick" mentioned in Harris' book. David Myrick and his wife Polly lived in a grand house, on a four-acre city lot, in downtown Eatonton for more than twenty years by the time Joel Chandler Harris was born there. Mrs. Myrick died soon after, but her husband continued to live in the house for decades to come. In addition to the expected deeds and wills, the archives revealed the Myricks' expenditures large and small, sacred and profane. Students discovered receipts for church donations and slave purchases and sales; for ordinary building materials for their house, carriage house, and formal garden; and for items of opulence, including $\$ 120$ for a sofa, $\$ 600$ for a carriage, and $\$ 1000$ for Mrs. Myrick's tombstone. They also found yearly receipts for income earned from leasing out dozens of slaves, as well as paying a doctor to care for those who were sick and a dentist to pull the rotten teeth of those who were suffering.

Digging into the primary sources in the archives and online allowed the students to compile a list of historical facts. This type of activity is important; it represents the way students began moving through the four levels of historical consciousness (see table 1) proposed by Catherine Duquette, a scholar of history education. Many students entered 
the project at Duquette's first level, as would most high school students, in which they were unable to contextualize the past. Research about Myrick moved them towards the second level, going beyond compiling data towards using it to tell the story of Myrick's life. The mention of the "Myrick Place" in Harris' book opened an investigation of local documents to transform the printed word back into a person. This process is an initial step in Seixas' model of historical thinking, where primary source evidence can provide a starting point for establishing historical significance and assembling facts into a cohesive story. Beyond locating David and Polly Myrick in time and place, however, the students were ultimately left without much more than an interesting bit of historical trivia.

Table 1 - Student Activities and Digital Tools by Level of Historical Consciousness and Vantage Point.

\begin{tabular}{|c|c|c|}
\hline $\begin{array}{l}\text { Vantage } \\
\text { Point }\end{array}$ & $\begin{array}{l}\text { Stages of Historical } \\
\text { Consciousness* }\end{array}$ & Student Activities and Digital Tools \\
\hline 1 & $\begin{array}{l}\text { Primary level: Students } \\
\text { collected primary source } \\
\text { documents related to inquiry } \\
\text { and began preliminarily } \\
\text { organizing initial evidence } \\
\text { into an outline for a cohesive } \\
\text { narrative. }\end{array}$ & $\begin{array}{l}\text { Students used primary sources to explore an historical } \\
\text { phenomenon (e.g., information contained in the appendix } \\
\text { to Uncle Remus, His Songs and Sayings) and began compiling } \\
\text { data related to that phenomenon (e.g., Ancestry.com; } \\
\text { Probate Court archives). They worked collaboratively in } \\
\text { groups to compile this information in a shared Google } \\
\text { Document. }\end{array}$ \\
\hline 2 & $\begin{array}{l}\text { Intermediate level: Students } \\
\text { interpreted primary source } \\
\text { documents and begin to } \\
\text { engage in historical } \\
\text { perspective taking. }\end{array}$ & $\begin{array}{l}\text { Students searched for Myrick in the Community History } \\
\text { Archive of the Uncle Remus Regional Library System } \\
\text { (http://uncleremus.advantage-preservation.com). } \\
\text { Students then worked in small groups to cross-reference } \\
\text { the digital (i.e., The Countryman) and paper archives (e.g., } \\
\text { court documents). They then came together as a whole } \\
\text { group to build perspective about the life of Myrick and } \\
\text { the history of Putnam. }\end{array}$ \\
\hline 3 & 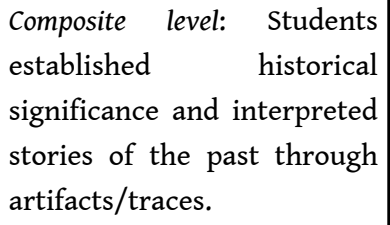 & $\begin{array}{l}\text { Students worked in conjunction with their teacher and in } \\
\text { small groups to reflect on the connections between newly } \\
\text { discovered local events and the larger whole. Digital tools } \\
\text { played less of a role than in previous vantage points. }\end{array}$ \\
\hline 4 & $\begin{array}{l}\text { Narrative level: Students } \\
\text { began to interpret the } \\
\text { complexity of the past and } \\
\text { how it relates to and informs } \\
\text { the present. }\end{array}$ & $\begin{array}{l}\text { Students digitized the stories and artifacts surrounding } \\
\text { Harris, Myrick, and Turner, and collected related oral } \\
\text { histories from community members. They then } \\
\text { geospatially situated those documents and recordings on } \\
\text { an interactive map of the state. }\end{array}$ \\
\hline
\end{tabular}

* Based on Duquette (57) 


\section{Vantage Point Two}

As students began to construct the Myrick story, they were caught off-guard by an interesting but unexpected phenomenon. They found a large set of receipts unlike anything found in most probate records. Document after document recorded countless purchases made by and for David Myrick, and most importantly, signed by other local residents serving as his "guardians." These receipts led to more questions than they answered, prompting students to explore the presence of "guardians" in what they had expected to be a fairly commonplace story. However, they had exhausted the resources available through digital and courthouse archives.

Reflecting Kirschenbaum's perspective that digital humanities work is a "social undertaking," students turned to local community members in hopes of finding additional stories or evidence that would help them better understand Myrick's circumstances. This collaborative work led to the discovery of a long-lost legal document associated with Myrick, now in private hands, and the historical context necessary to interpret it. The hand-written, worn and tattered artifact, yellowing with age, is a record of a hearing held at the Putnam County courthouse on October 10, 1825. A group of prominent local planters stood in court that day and testified that they knew David Myrick well and "looked upon him to be a person deprived of his reason and understanding in a great degree." They swore to the judge that, "David Myrick has been a terror to private families, and that he is in the habit of committing open and causeless acts of violence." "His conversations," they noted, had become, "incoherent and irrational." Finally, they asked the court to intervene and declare their friend and neighbor, "in no ways capable of governing himself or his estate." The court accepted the petition. Receipts for the next 40 years show a changing roster of very prominent Putnam planters appointed to serve as his financial guardians to protect his exceptional wealth and standard of living.

The discovery of this document, this exteriority of the history of Putnam, changed the nature of the students' work and opened a second vantage point. Myrick was declared incapable of managing himself by a court of law. His assets were taken from his control and placed under the legal authority of other planters in his community. For the students, Myrick stopped being just a wealthy slave owner referenced in the appendix of a book. He became instead a tangible figure in their minds. They came to see him as someone whose day-to-day existence was imperfect despite his enormous wealth, and who, just like them, experienced happiness, hopelessness, and struggle.

The second vantage point, then, covers the process by which students moved beyond facts-as-history and began connecting those facts into a meaningful narrative. Seeing causes and consequences through the documents compelled them to humanize Myrick, or as Seixas would term it, to preliminarily engage in the activity of historical perspective taking (9), a characteristic of Duquette's second, more interpretive level of historical consciousness (see table 1). The newly discovered court document recontextualized the information they had previously gathered, creating an opportunity to make sense of Myrick's story and imagine the circumstances of his plight.

2 The students continued to search for clues. This led them to conduct extensive research in the archives of Turner's The Countryman newspaper, which is currently available in digital format through the Community History Archive of the Uncle Remus Regional 
Library System (see <http://uncleremus.advantage-preservation.com>). Students and their teacher searched the archive and identified over three dozen articles, ca. 18221864, associated with Myrick's life and the disposition of his estate. These articles were distributed to students who then worked in small groups to cross-reference the digital (i.e., online editions of The Countryman) and paper archives (i.e., court documents, receipts), creating summaries of their findings. They then came together as a whole group to make sense of what they found.

This brought into focus exactly how the remaining members of the Myrick household retained their wealth even after David was no longer able-or permitted-to manage it. For nearly 40 years from when he was declared mentally unsound until his death, his guardians raised substantial amounts of capital through unfair dealings with local poor whites and on the backs of slaves. Multiple records indicated that the guardians engaged in decades of land deals with Putnam's middling class. They would then sue their lesser partners, asking the court to grant them full title to the land, only to sell the property for the benefit of David Myrick's ever-growing estate. Year after year, the guardians would also post advertisements in the newspapers saying that every January, on the courthouse steps in Eatonton, 20, or 30,40, or more of Myrick's growing number of slaves would be leased out to the highest bidders. The guardianship records show thousands of dollars per year flowing into the estate from these leases.

There was one act of callousness, however, that stood out above all others. In May 1835, Myrick's neighbors and guardians won yet another lawsuit, this time against a Putnam resident by the name of Greenberry Allen. As payment, they took from Allen what the newspaper identified as "one negro boy, six or seven years old, named Harper" (The Georgia Journal, Milledgeville:4). Then they sold him by auction on the courthouse steps (see Figure 2).

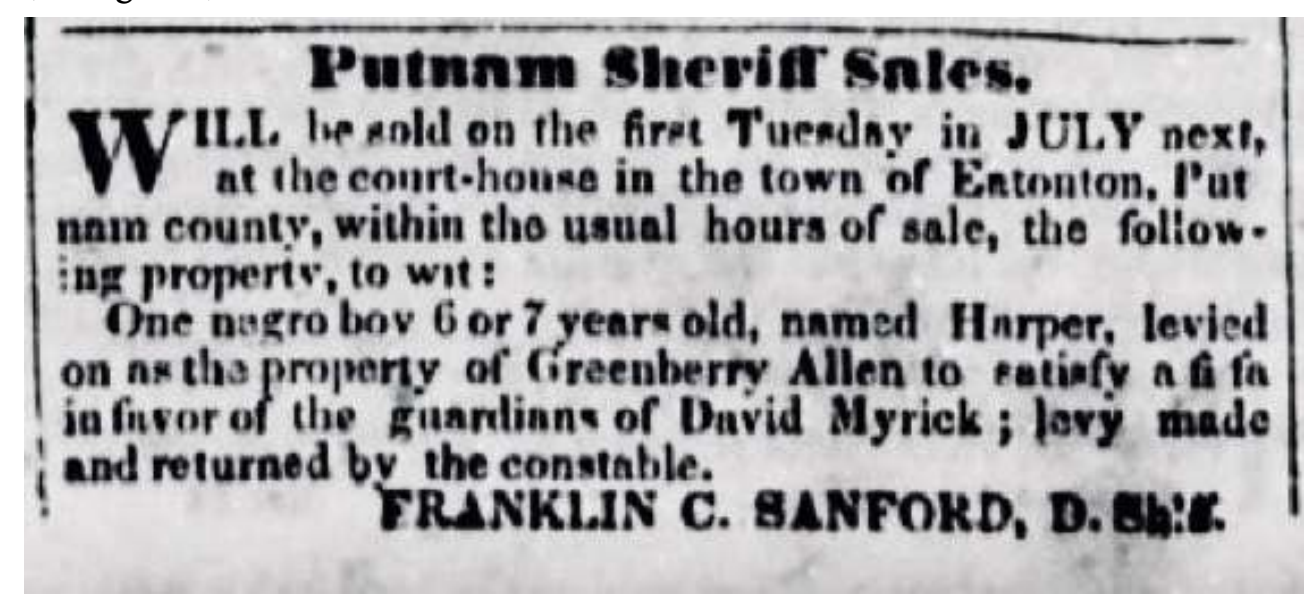




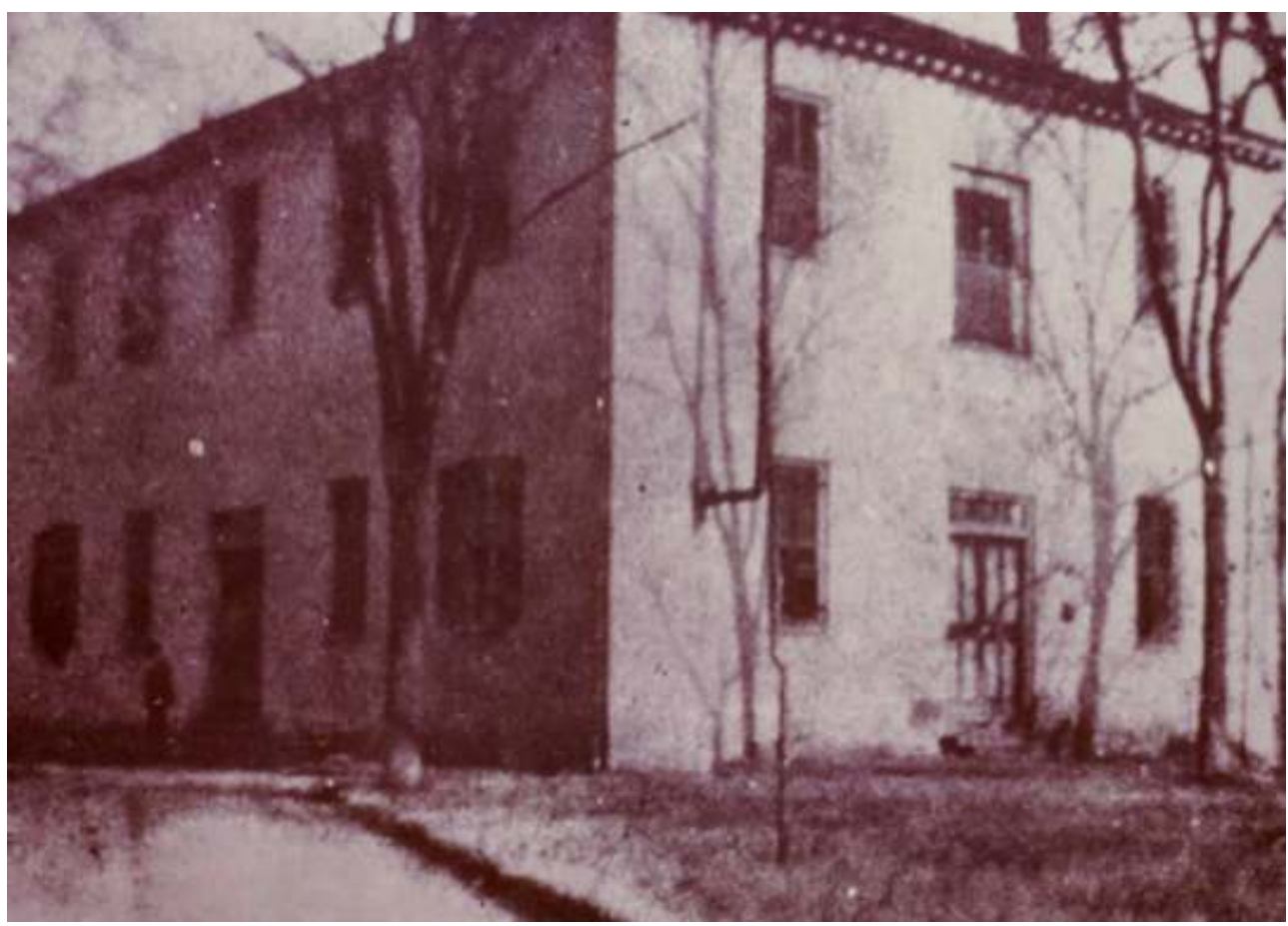

Figure 2 - Advertisement for the sale of Harper in the (Milledgeville) Georgia Journal, 12 May 1835 (above) and photo of the 1824 Putnam County courthouse (below). Courthouse photo courtesy of Mr. Clayton Hargrove, Putnam County Probate Court and the Eatonton-Putnam Historical Society.

The gravity of this discovery was profound. In "The Pedagogical Insistence of Public Memory," Roger Simon explored how recounting traumatic and dehumanizing experiences has the potential to elicit in readers a sense of accountability for the past (199). The legal court document and the ensuing sale of a little boy created emotional dissonance for students, compelling them to engage further in Seixas' historical perspective taking. There is no record of the rest of Harper's life, no way of knowing if he was one of the 7,000 still enslaved in Putnam at the start of the Civil War. Yet the students unearthed the story of a small child who, at an age close to their own, was taken from his mother and sold as property. They had to confront in deeply personal ways that this small boy once walked the same ground that they now walked, not as a human being but an asset, a line on a ledger. They had to reflect on what this event meant for the child and those who loved him.

In this way, the second vantage point opened a space for what Simon has explained as, "not only a taking in of stories, but a taking of stories into account" (186). Students were no longer just compiling facts. Rather they engaged in Duquette's second level of historical consciousness, interpreting events that happened in the past to gain perspective about Myrick's life and his guardians' actions. If the story had taken some unforeseen turns in moving from Harris to Remus to Myrick, the most unexpected of all was the accidental discovery of young Harper. He was both a Putnam resident and a child, close in age to the students who discovered him at time he underwent a horrific trauma. His story took the students' imagined accounts of slavery, introduced through a slave song documented by Harris and contained in Uncle Remus, and made it tangible and real. The students' work became more than an academic exercise in a history class. The stories of Myrick and, in turn, Harper, served as opportunities for students to come to terms with the complexities of the past. 


\section{Vantage Point Three}

The story does not end with the guardians or the heartbreaking story of Harper being sold on the courthouse steps. Despite the fact the students had constructed a cohesive narrative based on primary source evidence, they had only just begun to discover and articulate the historical significance of Myrick's life. This is the third vantage point.

David Myrick died in November 1862. Over the course of the year and a half following his death, Joseph Addison Turner and his apprentice, Joel Chandler Harris, published more than a dozen legal notices and accounts in The Countryman pertaining to Myrick's land and slave sales. Turner, proud master of Turnwold and the newspaper's publisher, took those sales as an opportunity to point out to readers what he saw as a glimpse of the world in its rightful order. Earlier that year he had issued a reprint of his popular epic poem, "The Old Plantation" in which he waxed nostalgic for the world created by his parents'-and Myrick's-generation.

Putnam County in the 1810 s and early 1820 s was, at least in Turner's imagination, a dense forest where humble white settlers were besieged by Indians and wild animals. Yet by the time of his birth in 1826, he wrote, the hard work of people like his parentsand Myrick-had transformed wild chaos into fertile fields: "Where tangled vines once walled the settlers round, / The snowy cotton all the valley crowned." They eventually reaped what they sowed, he continued, and by his childhood, "flowing wealth in fattening coffers poured," and they, "built costlier homes, and barns with plenty stored." All this had been accomplished by the unified interests of noble white landowners and the contented, appreciative workforce they just happened to own. Indeed, he recalled how he grew up believing he had a kindred bond with his father's chattel: "The little master with the little slave, / All gaily happy in their boisterous glee, / As equals "neath the old familiar tree" (Turner, On the Plantation: 4).

Turner's reprint of his poem coincided with Myrick's death, which coincided with a crucial moment for all Georgia slaveowners in the middle of the Civil War. Neither the poem nor notices about Myrick's estate were mere idle chatter about local memories or local happenings, but efforts to balance a tipping ship. Lincoln's Emancipation Proclamation had shaken Turner with its potential to unleash wide-scale insurrection. The pages of The Countryman throughout 1863 were filled with appeals for strict plantation management and increased slave patrols. By year's end he felt compelled to print a portion of the Georgia Slave Code, warning of the danger of idle talk in provoking a mass-exodus of slaves as federal troops began their march towards the state's interior (Smith, 109). "Negro slavery is the south," he proclaimed in a long, defensive preface to "The Old Plantation," "and the south is negro slavery" (Turner, On the Plantation: 4$)$.

Imagined bonds of affection may have made the South's "peculiar institution" easier to live with, but they were a luxury wrapped around an economic reality which Turner could no longer afford to deny. David Myrick's death provided him with what he seems to have believed was a much-needed opportunity to counsel his readers that slaves were still a solid investment, even if the future appeared uncertain. In an article in the February 2, 1864, edition of The Countryman, he celebrated that,

a portion of the negroes belonging to the Myrick estate were sold at the

following high prices [...] Drucilla and Son, 23 and 11-\$5050; Frances 
and three children, 39-5-2-and 7 months- $\$ 10,000$; Polly, 17 and fancy

$-\$ 7,000[. .$.$] There were 21$ negroes sold, at an average of $\$ 2727.61$ each.

When the number of children and old and diseased negroes in the Total is

taken into consideration, it will be seen that these slaves sold for more than

in the case of any sale yet recorded (6).

\section{and literary curiosity and became important to history. Students were asked to} juxtapose the accounts in The Countryman with their knowledge of Lincoln's Emancipation Proclamation, which in turn invited them to develop an historical perspective on Turner's motives. It prompted them to consider the impact of the Emancipation Proclamation from Turner's perspective, held up against the sale of Harper, and through the events of David Myrick's life. For many students, Harper's story transformed two abstract events (that is, the culmination of abolitionist effort and the counterweight of pro-slavery thought) into something both concrete and emotional. It created an opportunity for students to understand how history, as a broad and abstract concept, can relate to and be recontextualized by the people and events that shaped the place they call home. This form of interpretive work reflects Duquette's higher Composite Level of historical consciousness (see table 1), which is characterized by activity such as establishing relationships between the different documents and identifying the causes and consequences of the events of the past.

At this level, digital tools played less of a role in student learning than in previous vantage points. The overall goal was not to produce an external artifact of their learning but facilitate an internal shift in the way they made meaning out of the past. They worked in conjunction with their teacher and in small groups to reflect on the connections between newly discovered local events and the larger whole. Throughout this process, they encountered place-based history as what education scholar Sirkka Ahonen has described as "a necessary asset in the orientation to life," and began to develop new perspectives on how the present has grown out of the past (700).

\section{Vantage Point Four}

41 Given Turner's rhetoric at the time, one might naturally assume that his young apprentice's interest in Myrick was also purely financial. Given Turner's reputation then and now as a staunch proslavery advocate, one might also assume that his young apprentice shared his view on the rightful order of masters and slaves in the world. There are clues that neither was so. After nearly a century of writing about Harris, scholars have only recently begun to consider that he had highly conflicted views on the institution of slavery versus the humanity of those who were enslaved (Bickley: 65, 145; Walker: 32).

Harris left behind no indications that he ever publicly questioned the right of Turner, Myrick, or anyone else, to own other human beings. In his private thoughts, however, he may have wondered about their rationale for keeping people in bondage. He was the only child of a poor, single, washerwoman. Their lives were made possible by, but also at the mercy of, the county's elite planters. Harris and his mother lived in a small cabin behind the grand city house of one of them, a quick walk from the Myricks, and his education was a gift of their generosity. He would have witnessed first-hand the annual gathering and leasing of dozens of Myrick's slaves on the courthouse lawn. He seems to 
have skirted the edge of empathy for those who were enslaved, at least in that he recognized that they, like him, lived at the mercy of elite planters. Turner, he later recalled, once told him that slave patrols never visited Turnwold because, "people who treated their negroes right had nothing to fear from them" (Harris, On the Plantation: 69). Harris, however, had misgivings. In his 1892 account of his life at Turnwold, he wrote how he had befriended and aided runaway slaves from neighboring plantations and mocked the "foolish and sometimes fruitless errands" of the slave "patter-rollers" (Harris, On the Plantation: 65).

The scholar Robert Cochran similarly suggested that Harris had a very complicated relationship with slavery. In a 2004 essay, Cochran pointed out that Harris' earliest books were built around the central void of an absent father (32). The first several Uncle Remus volumes function as an ongoing dialogue between Remus and the young son of the plantation owner. The little boy constantly reappears at old man's side, looking for the guidance of a strong male mentor, and is consoled each time with yet another Br'er Rabbit story. Even when Harris shifted his structure to write about the Civil War and the arrival of Union soldiers at plantation, the white father-figure was still absent and it was Remus who forcefully protected the little boy and his mother. This perspective on Remus as a paternal figure in Harris' life makes sense given that he lived in the world of Putnam's planters, but was not of that world.

Putnam's contemporary generations are not of that world, either. Many of them, like their grandparents and great-grandparents before them, were born into a place owned by, shaped by, and controlled by others. Approaching Harris' work from this perspective reveals the author not as two-dimensional reflection of an imagined and white-washed past, but a more complex human being who struggled with his own time and place much as modern residents struggle with theirs.

In light of Cochran's argument, perhaps it is at least possible that Harris specifically identified what he called "The Myrick Place," in the appendix to his first Uncle Remus book because he was questioning the world the slaveholders made. At the same time, he benefited immensely from the stories he appropriated from Turnwold's slaves. Harris is a complicated figure, personally and literarily difficult for those seeking to make sense of the past. He may have accurately, almost anthropologically, preserved the stories and songs and culture of those who were enslaved, but also made himself into an international celebrity on the property of others.

Students' ability to engage in this level of historical perspective taking opened up the fourth vantage point. They began to recontextualize Harris as an opportunity to explore the centuries-old intersectionality between race and class, wealth and power. Each of the first three vantage points allowed students to confront representations of the past. They witnessed how meaning began to shift as they moved from the printed page to the fields at Turnwold, into digital archives, brick-and-mortar archives, the community, and back again to the monuments and signs that are the exterior manifestations of Putnam's identity. The fourth vantage point, then, appeared when students began to see how each of the previous three overlapped.

The process of visualizing these connections engaged students with history at a conceptual level. Using Harris, Turner, and Myrick as a lens on Putnam's past allowed students to move through historical concepts such as identifying cause and consequence, mapping continuity and change, and debating significance. They gained the ability to weave together the results of this intellectual journey into an historical 
argument, illustrating what Duquette refers to as the Narrative Level of historical consciousness (see table 1). They came to realize that each step along the way, or each vantage point, was both complete unto itself and only achieved its full meaning in concert with the others.

The fourth vantage point brought the students full circle, back again to the monuments, signs, and museums that adorn Putnam County and celebrate Harris' work. They, like their families before them, have long wrestled with the assumption that these markers reflect an official nostalgia for the past and a willingness to overlook the struggles through which their ancestors lived. Finding and methodically exposing the unexpected roots of these exteriorities of history, these ways by which Putnam has defined itself to the outside world, allowed them to consider that past narratives were incomplete rather than incorrect. Nothing was as simple or straightforward as it once seemed. Uncovering this overlooked history was the key to beginning to understand the causes and effects of the economic, racial, and social issues with which Putnam's students, like so many across the rural South, must contend on a near-daily basis. Through this process they were finally able to begin to make sense of the past and see its connections to their present.

\section{Humanities, Digital and Embodied}

For some, our presentation of this digital humanities project may seem somewhat unconventional. The structure of this paper, however, was purposeful. Humans grope among what Ralph Waldo Emerson once famously called the "dry bones of the past," futilely manipulating them like pieces of an incomplete puzzle in an attempt to understand something of who we are and where we come from (12). Jonathan Sterne, scholar of culture and technology, similarly reminded us that, "We make our past out of the artifacts, documents, memories, and other traces left behind" (19). GVHP is an effort to bring the tools of the historian and digital humanist out into the world, where they might be of some use in making sense of the traces that are left behind. It is a digital humanities project designed around process rather than product, focused instead on exploring and analyzing those traces as a means of making our past.

The project's work in Putnam County is not about uncovering truth with a capital "T," but truth as an instantiation of meaning at a given point in time that is, by its very nature, always incomplete. Our work in the field with students, and as an effort in the digital humanities, is guided by a single overarching belief: we make the past not merely as an abstract assemblage of facts and knowledge, but rather by embedding in a specific place to negotiate how multiple stories of that place, at different points in time and from different perspectives, can evoke different-and equally plausible-meanings.

51 This paper's construction as a series of vantage points is a reflection of that agenda. The four vantage points laid out here do not represent a complete truth about Myrick, Harris, or even the nineteenth-century past. Instead, they reflect the way students moved away from history as an abstract assemblage of facts and towards deeper levels of historical consciousness. What began as a group of high school students in the fields of what remains of Turnwold Plantation became much more. Reading about "The Myrick Place" in the appendix of Harris' first Uncle Remus volume triggered a curiosity about Putnam's history. Fact finding slowly grew into sense-making, where each successive vantage point revealed additional meanings about Myrick's life and the 
traces of Putnam's past that had been left behind. The result was the development of new perspectives on Harris as a complex literary and historical figure and the local exteriorities of history that celebrate his work. Putnam's students progressed through each of the vantage points not only as a process of uncovering the history of their home, but also, and perhaps more importantly, as a path towards understanding how that history shapes and has meaning in their present.

This approach capitalizes on the way human cognition works from an embodied perspective. As described by Lynn Liben, embodied cognition assumes that mind, body, and environment are linked, and that our thinking is a product of the way these three entities interact (198). This interaction is bi-directional. Mind and body make sense of the world, which affects our perception of our environment. This perception is based on the information available at a given point in time. New information leads to additional sense-making, and our perception of the world changes with it. This perspective reminds us that, on our own, we cannot access anything beyond our physical bodies, in our own time and place. Thus, the exteriorities of history, those traces and artifacts that remain, are all we have to make sense of the past based on the experiences we have in the present.

From an embodied perspective, those "dry bones," those traces of the past that remain today, are more than data points. They serve as symbolic representations that give us the ability to picture and find meaning in situations that we can never physically experience (Wilson: 629). The meaning we make is not fixed and rigid but something we construct. It takes different form at different points in our lives because it is constructed in concert with our understanding of the world, an understanding that is constantly evolving. Knowing that past through its traces, then, is not about accumulating a more complex data set; rather, it is about seeing in those traces the commonalities that connect us all. This goes beyond fact-finding, focusing more on understanding the larger constructs at play in the world, both in the past and present: wealth, power, justice, morality, respect, and, above all, what it means to be human as part of a community of humans that stretches back across the generations. There is power in knowing that other humans have struggled, suffered, and survived the issues we all contend with in some way. In this context, history becomes a preliminary step towards trying to exist in the world in a way that connects with others, overcomes obstacles, and builds a life that has meaning.

If this process is at its core a description of what humanists have always done, it is in the next stage of our project that the work becomes at once both fully digital and fully embodied. Students digitally preserved the larger details of the story presented in this paper for the Georgia Virtual History Project's (GVHP) website (see figure 3). The stories and artifacts surrounding Harris/Myrick/Turner were digitized, then geospatially located on an interactive map of the state. As part of this work, students also collected oral histories from local community members to bring additional perspectives to the events of the past. Technology therefore served as a tool for transforming the artifacts of the past into symbolic representations that helped students not only find meaning in situations they had never experienced, but also share that meaning with others. It is worth noting that this paper, too, will become part of the linked data set. It is a step that is unique to the methods and possibilities of digital humanities. What was once the purview of the professional historian, namely the ability to see and analyze the overlay of these various and previously unconnected 
parts of a story, has been transformed into a very public space for visualizing and discussing the ways in which Putnam's past connects with its present.

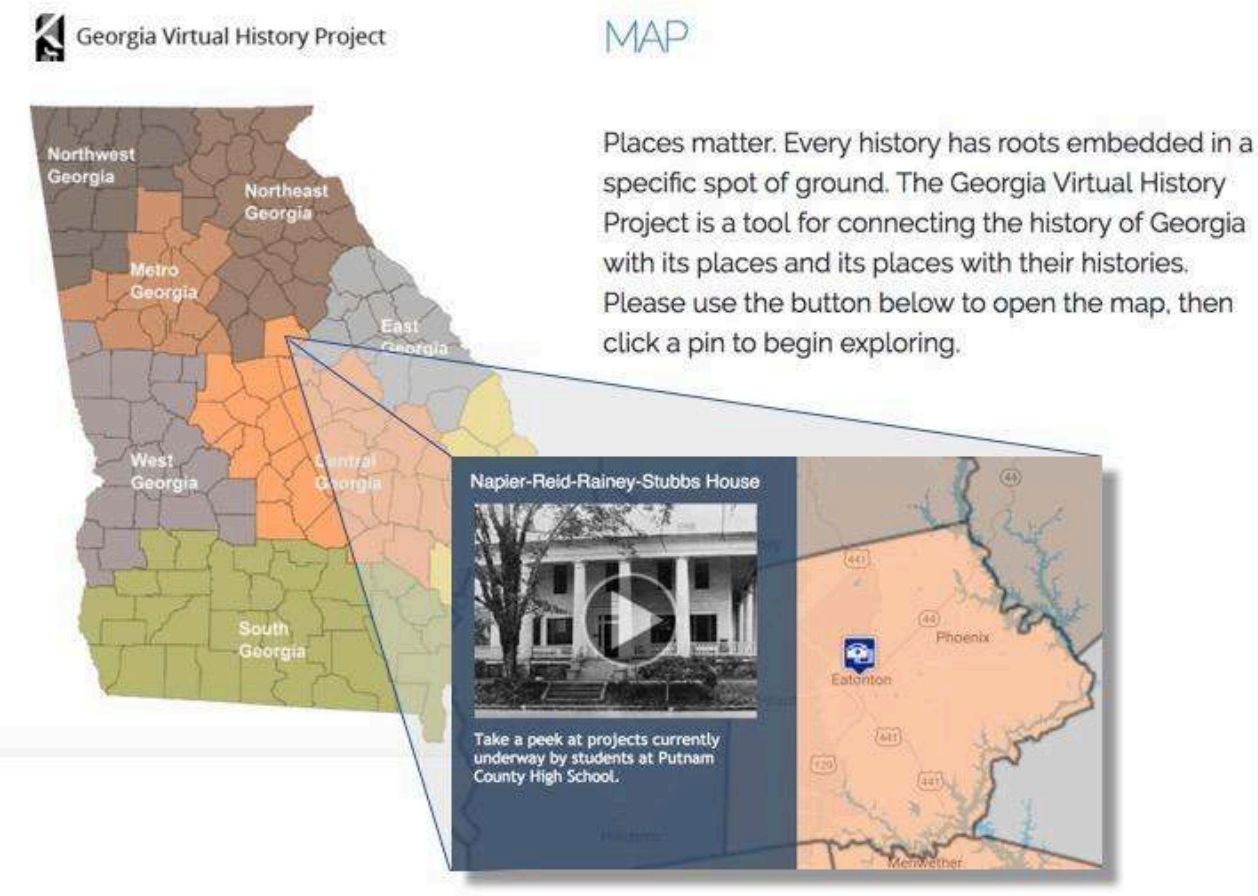

Figure 3 - The Georgia Virtual History Project website (<https://virtualgeorgia.org>) contains geolocated media (e.g., videos, resource links, images), created by project participants, that tell the stories of the past.

Roger Simon once wrote, "Remembrance thus is a reckoning-an accounting-that beckons us to the possibilities of the future, the possibilities of our own learning," by asking us to, "live relationally, to live justly and publicly, with others, both living and dead" (187). Our project is an attempt to do just that. It was not developed in a lab at the university, but rather through sustained engagement with a local school and community. The students and their community are the subjects of, as well as both the producers and consumer of the work. The goal has never been to create a reproducible recipe for recreating an out-of-the-box digital humanities project but was built from the start to do something radically different.

Process here is emphasized over product, though both are important aspects of the learning that takes place. The result is an approach to the digital humanities that, we hope, reveals a way of knowing and being in the world. It is not enough to gather and analyze facts about the past. Rather, our aim is to help cultivate an attitude that emphasizes meaning-making, where meaning is constructed through interaction between mind, body, and the world in which we live. In this way, our process positions the digital humanities as a tool for working within and for the benefit of a community, as a way of connecting with the past to bring understanding to the present and suggest possibilities for the future. Students' work on this project will allow subsequent generations of peers and educators to recreate the journey by constructing vantage points in their own lives and through their own communities. Preserving that work through the GVHP website invites others to voyage out into the world and begin the process anew. 


\section{BIBLIOGRAPHY}

AHONEN Sirkka (2005), “Historical Consciousness: A Viable Paradigm for History Education?”, Journal of Curriculum Studies, 37(6), 697-707.

BICKLEY R. Bruce (1978), Joel Chandler Harris, A Biography and Critical Study, University of Georgia

Press.

CoCHRAN Robert (2004), "Black Father: The Subversive Achievement of Joel Chandler Harris," African American Review, 38(1), 21-34.

DUQUETTE Catherine (2015), "Relating Historical Consciousness to Historical Thinking Through Assessment", K. Ercikan \& P. Seixas (eds), New Directions in Assessing Historical Thinking, Taylor \& Francis Group, 51-88.

EMERSON Ralph Waldo (1888), Emerson's Complete Works (Vol. 1.), Houghton: Mifflin and Company. GoLD Matthew K., \& KLEIN Lauren F. (2016), “Introduction: Digital Humanities: The Expanded Field", Debates in the Digital Humanities 2016, University of Minnesota Press, IX-XV.

HARRIS Joel Chandler (1880), Uncle Remus, His Songs and Sayings, D. Appleton \& Company.

HARRIS Joel Chandler (1892), On the Plantation: A Story of a Georgia Boy's Adventures During the War, D. Appleton \& Company.

KIRSCHENBAUM Matthew (2012), "What is Digital Humanities and What's it Doing in English Departments", M. Kirschenbaum (ed.), Debates in the Digital Humanities 2012, University of Minnesota Press, 3-11

LIBEN Lynn S. (2008), “Embodiment and children's understanding of the real and represented world", W. F. Overton, et al. (eds), Developmental perspectives on embodiment and consciousness, Taylor \& Francis Group/Lawrence Erlbaum Associates, 191-224.

Mixon Wayne (1990), "The Ultimate Irrelevance of Race: Joel Chandler Harris and Uncle Remus in Their Time", Journal of Southern History, 56(3), 457-480.

PANNAPACKER William (2013), "Stop Calling it Digital Humanities and 9 Other Strategies to Help Liberal-arts Colleges Join the Movement", Chronicle of Higher Education, <www.chronicle.com/ article/Stop-Calling-It-Digital/137325>.

SEIXAS Peter (2017), “A Model of Historical Thinking”, Educational Philosophy and Theory, 49(6), 593605.

SCHREIBMAN Susan, SIEMENS Ray \& UnSWORTH John [eds] (2015), A New Companion to Digital Humanities, John Wiley \& Sons.

SIMON Roger (2004), “The Pedagogical Insistence of Public Memory”, P. Seixas (ed.), Theorizing Historical Consciousness, University of Toronto Press, 183-164.

SMITH Christina Lea (2015), The Countyman: Joseph Addison Turner and the Cultural Construction of Confederate Nationalism (MA thesis), Illinois State University.

STERNE Jonathan (2003), The Audible Past: Cultural Origins of Sound Reproduction, Duke University Press.

THE Georgia Journal (23 June 1835), Putnam Sheriff Sales, Milledgeville, Georgia, p. 4. 
TURNER Joseph Addison (1862), On the Plantation. A Poem. By the Wanderer, Eatonton, Georgia: Countryman Print.

TURNER Joseph Addison (1864), "High Prices for Negroes”, The Countryman, 6.

WALKER Alice (1988), “The Dummy in the Window: Joel Chandler Harris and the Invention of Uncle Remus", Living by the Word: Selected Writings 1973-1987, Harcourt Brace Jovanovich, 25-32.

WiLson Margaret (2002), “Six Views of Embodied Cognition”, Psychonomic Bulletin \& Review, 9(4), 625-636.

\section{ABSTRACTS}

Digital Humanities in the U.S. has often focused on digital design over how humanities content might be used. Our Georgia Virtual History Project was built from the opposite direction. Rather than simply creating digitized humanities, we are dedicated to exploring the ways in which the digital world can help us construct more robust, place-based scholarship that impacts the lives of those who make and use it. We want our work to exist both online and out in the world, to speak equally to scholars and the general public, and to demonstrate that the humanities are not the purview of the academic elite but rather an essential tool for reaching out and giving voice to traditionally underserved populations.

The paper situates the Georgia Virtual History Project within the universe of digital humanities scholarship, then explores a case study of how it works in the real world. By explaining both our project and how it has been used in an economically disadvantaged rural school system, we will present a model that is an attempt to remake public K-12 education-and digital humanities-as an embodied experience.

Aux États-Unis, les humanités numériques ont souvent mis l'accent sur la conception numérique plutôt que sur la façon dont le contenu des humanités pourrait être utilisé. Notre projet d'histoire virtuelle en Géorgie a été construit dans la perspective inverse. Plutôt que de simplement créer des humanités numérisées, nous nous consacrons à explorer les façons dont le monde numérique peut nous aider à construire une recherche plus robuste et plus adaptée au milieu qui influe sur la vie des personnes qui la créent et l'utilisent. Nous voulons que notre travail existe à la fois en ligne et dans le monde réel, qu'il s'adresse autant aux chercheurs qu'au grand public et qu'il démontre que les sciences humaines ne sont pas du ressort de l'élite universitaire mais plutôt un outil essentiel pour atteindre et donner la parole aux populations traditionnellement désavantagées.

L'article situe le Georgia Virtual History Project dans l'univers de la recherche en humanités numériques, puis explore une étude de cas de son fonctionnement dans le monde réel. En expliquant à la fois notre projet et la façon dont il a été utilisé dans un système scolaire rural économiquement défavorisé, nous présenterons un modèle qui est une tentative de transformer l'enseignement public de la maternelle au lycée - et les humanités numériques - en expérience concrète.

INDEX

Keywords: digital humanities, historical consciousness, history education, curriculum and instruction, community-based learning

Mots-clés: Sciences humaines numériques, conscience historique, enseignement de l'histoire, programme d'études et enseignement, apprentissage collectif 
AUTHORS

\section{CHRISTOPHER R. LAWTON}

Georgia Virtual History Project, USA

THEODORE J. KOPCHA

University of Georgia, USA

KATIE WALTERS

University of Georgia, USA

\section{CEREN OCAK}

University of Georgia, USA 